\title{
Evaluation of the Residency Programs of the Federal University of Rio Grande do Sul from the residents' view
}

\author{
Avaliação dos Programas de Residência da Universidade Federal do \\ Rio Grande do Sul na percepção dos residentes
}

\author{
Juliane KRÄMER ${ }^{a}$ (D) , Aline Blaya MARTINS ${ }^{a}$ (i), Renato José DE MARCHI ${ }^{a *}$ (1) \\ aUFRGS - Universidade Federal do Rio Grande do Sul, Faculdade de Odontologia, Porto Alegre, RS, Brasil
}

How to cite: Krämer J, Martins AB, De Marchi RJ. Evaluation of the Residency Programs of the Federal University of Rio Grande do Sul from the residents' view. Rev Odontol UNESP. 2020;49:e20200008. https://doi.org/10.1590/18072577.00820

\begin{abstract}
Resumo
Introdução: As residências multiprofissionais em área profissional da saúde ganharam espaço a partir da Lei ${ }^{\circ} 11.129$ de 2005. Constituem-se como uma modalidade de ensino de pós-graduação Latu-sensu, com a intenção de capacitar profissionais para trabalhar no Sistema Único de Saúde (SUS). Objetivo: Este estudo teve por objetivo investigar a atual situação, desde uma perspectiva de satisfação com a formação, com cursos de Residência, dos residentes da Universidade Federal do Rio Grande do Sul. Material e método: Constitui-se de um estudo com abordagem mista. 0 segmento quantitativo ocorreu através da aplicação de um questionário para todos os residentes participantes do Programa de Residência da UFRGS no ano de 2018. 0 estudo de abordagem qualitativa foi realizado através da técnica de grupos focais. Resultado: Totalizaram 81 participantes na abordagem quantitativa e nos grupos focais participaram 14 residentes, pertencentes ao programa de Saúde Bucal. Os resultados quantitativos representam que os residentes receberam pouca ou nenhuma orientação no início do programa. Os resultados qualitativos apresentam questões que permitem fazer inferências acerca da insatisfação e desconhecimento dos residentes acerca do funcionamento dos Programas. Conclusão: Destaca-se que os residentes reconhecem que há ainda questões de gestão do programa a serem aprimoradas, bem como de reconhecimento da sua importância dentro da Universidade.
\end{abstract}

Descritores: Aprendizagem; ensino; pós-graduação latu sensu; prática profissional.

\begin{abstract}
Introduction: The multi-professional residencies in the Health area started to improve after the Law $n^{\circ} 11.129$ of 2005 . They are a modality of Latu-sensu graduate education, with the purpose of training professionals to work in the National Unified Health System (SUS). Objective: This study aimed to investigate the current situation, from a perspective of satisfaction with the training in Residency courses, with the residents of the Federal University of Rio Grande do Sul. Material and method: It is a study with a mixed-methods approach. The quantitative section was conducted through the application of a questionnaire to all residents participating in the UFRGS Residency Programs in 2018. The qualitative part was conducted using the focus group technique. Result: There were 81 participants in the quantitative component, and 14 residents of the Oral Health program participated in the focus groups. The quantitative results showed that residents received little or no guidance at the beginning of the program. The qualitative results showed questions that allow inferences about residents' dissatisfaction and lack of knowledge about the functioning of the Programs. Conclusion: Residents recognize that there are still issues with program administration to be improved, and more especially, the recognition of the importance of the Residency Programs within the University.
\end{abstract}

Descriptors: Learning; teaching; latu sensu graduate; professional practice. 


\section{INTRODUCTION}

The Unified Health System (SUS) emerges within the scope of the Brazilian Health Reform. It was a movement that started in 1970 and had its breakthrough and consolidation in 1986 at the VIII National Health Conference ${ }^{1}$. Multi-professional Health Residency Programs appear subsequently to rethink practices within SUS, through training and education. Separating the Residencies from the concepts of the Unified Health System such as integrality, equity and universality is impossible ${ }^{2}$. They advocate the use of active and participatory methodologies, through permanent education and in-service teaching 3 .

The history of Multi-professional Integrated Residencies in Health is very relevant. The program was created in 1976 by the State Health Secretariat of Rio Grande do Sul, in a Healthcare Unit called São José do Murialdo, the first Residency in Community Medicine in the country ${ }^{1}$. Its proposal was to train professionals with a more humanistic view and a critical profile, focused on solving the needs of the population ${ }^{4}$. In just two years' time, the Murialdo Residency became multi-professional.

According to the Report of the National Commission for Multi-professional Residencies in Health (CNRMS) 2007/20095, another training of a multi-professional team in the country, still in the 70s, was the TAS (Advanced In-Service Training). This was an initiative of the National School of Public Health of the Oswaldo-Cruz Foundation (ENSP-FIOCRUZ). Decree 80.281, of 1977, created the Medical Residency as a latu-sensu graduate modality, characterized by in-service training, and considered the gold standard of medical specialization in $1978^{6}$.

Resolution No. 2877 of 1998 of the National Health Council (CNS) established which professions in the Health area would meet the requirements of the program. They are: social workers, biologists, biomedical scientists, physical education professionals, nurses, pharmacists, physiotherapists, speech therapists, physicians, veterinarians, nutritionists, dentists, psychologists and occupational therapists.

Multi-professional residencies and those in the Health professional area gained recognition after the enacting of Law No. 11.129 of $2005^{8}$. They are a teaching modality of the latu-sensu graduate program to train professionals to understand the multi-causality of individual and collective processes, contextualizing individuals in their environment ${ }^{9}$.

Given the above and the concern of residents entering the Residency Program in the Health professional area in the Multi-professional and Uni-professional modalities of the Federal University of Rio Grande do Sul in 2017, as well as the range of difficulties in the process of consolidating the Unified Health System in Brazil, many doubts arise regarding the process of training the residents. Program evaluations are essential for assessing the quality of the courses. According to Resolution 7 of the National Commission for Multi-professional Residencies in Health (CNRMS) ${ }^{10}$, November 13, 2014, the evaluations are a method of encouraging the improvement of the Residency Programs, and will be conducted by CNRMS.

Thus, this study aimed to evaluate different situations experienced by residents, in their work and training places, at the Federal University of Rio Grande do Sul (UFRGS), through a quantitative and qualitative study ${ }^{11}$.

\section{MATERIAL AND METHOD}

The study was conducted in Porto Alegre, RS, in the professional areas of the residents, health services and UFRGS facilities. First, multiple-choice questionnaires were applied. Afterward, focus group research was conducted ${ }^{12}$. 
The target population of this study was composed of graduate students participating in the Multi-professional and Uni-professional Health Residency of the Federal University of Rio Grande do Sul in 2018. The UFRGS Residency Programs that were invited to participate were the Integrated Multi-professional Residency in Public Health; in Children's Health: violence and vulnerabilities; Public Mental Health; and, Uni-professional Integrated Residencies in Oral Health, and Animal and Public Health.

The individuals included in this study were all residents in the first, second and third years of training in the UFRGS Residencies who agreed to participate in the quantitative segment of the study, totaling 81 participants. These 81 respondents represent four residency programs of the university: Multi-professional Integrated Residencies in Public Health and in Public Mental Health; and, the Uni-professional Integrated Residencies in Oral Health and in Animal and Public Health. The residents and coordinators of the programs were invited, for a maximum of three times, to participate in the study. The residents of each program were invited to participate in focus groups for the qualitative part ${ }^{11}$, integrating two focus groups from the Integrated Residency Program in Oral Health (RISB). The study was conducted with the consent of the participants, obtained through their signing of an informed consent form.

The study was conducted by a second-year resident from the RISB of Family and Community Health (SFC). Questionnaires were applied, with quantitative variables dealing with the training, participation and satisfaction of residents in the residency programs. Afterward, meetings to conduct focus group research were held with those who agreed to participate ${ }^{12}$.

The researcher constructed the questionnaire based on the resolutions found in the CNRMS publications as well as on personal perceptions about the management and administration of the residency programs. There were twenty-five open and closed questions. The researcher took the questionnaires, personally, to the training locales of each program. The residents were informed as to the objective of the study at each meeting and were guided with regard to filling out the questionnaire.

Residents who accepted the invitation participated in the focus groups. Two focus groups were conducted. An interview with trigger questions was followed, the interviews were recorded, and annotations of the perceptions of the researcher were made in the form of field notes and memos. The researcher was the mediator for the focus groups, which lasted an average of 60 minutes. The participants were identified by the letter " $R$ ", initial of the word "resident", followed by an Arabic number (R1, R2, R3 ...). The focus groups were identified by the letters "GF", initials of the words "group" and "focus", also followed by a numeral, in order to maintain the confidentiality of the participants ${ }^{12}$.

\section{Data Analysis}

The data collected in the questionnaires were tabulated and analyzed statistically. The analysis was conducted by calculating percentages and using the Chi-square test. The SPSS 21.0 software was used for the quantitative analysis. The information obtained in the focus groups was analyzed based on Grounded Theory research method ${ }^{13}$. The texts were transcribed verbatin. In the first phase of qualitative analysis, codes were associated with specific excerpts in the texts, in the process of open coding. After comparative readings and analyses of the codes, axial coding was conducted in which related codes composed the analytical categories. The categories were analyzed according to their domains and characteristics. Their relationships allowed the development of the conceptual themes of the study. Memos were used to construct the analyses at each step of the study. Field notes, created right after the focus groups, were also used as a unit of analysis ${ }^{13}$. The processes described here were conducted by the principal investigator $(\mathrm{JK})$, and were audited at each step by a researcher with expertise in qualitative research and Grounded Theory (RDM). 


\section{Ethical Aspects}

This study followed Resolution 466/2012 of the National Council of Health (CNS), and was approved by the Research Ethics Committee of UFRGS, decision no CAAE 86163018.8.0000.5347. All participants authorized the use of the information by signing the Informed Consent Form, in two copies: one held by the researcher and the other given to each participant.

\section{RESULT}

\section{Quantitative Results}

The questionnaires were applied to the residents of the Multi-professional Integrated Residencies in Public Health and Public Mental Health; and, the Uni-professional Integrated Residencies in Oral Health, and Animal and Public Health, totaling 81 respondents. The analysis of the profile of the participants shows that most are women, $82.7 \%$ (Table 1 ), and the ages ranged from 22 to 37 years.

Table 1. Characterization of the sample according to sex. Participants $=81$

\begin{tabular}{cccccc}
\hline & & $\mathrm{n}$ & $\%$ & Valid percentage & Accumulated percentage \\
\hline \multirow{4}{*}{ Valid } & Female & 67 & 82.7 & 82.7 & 82.7 \\
& Male & 14 & 17.3 & 17.3 & 100.0 \\
& Total & 81 & 100.0 & 100.0 & \\
\hline
\end{tabular}

We will highlight some of the questions that were addressed in the questionnaire. The first question that addresses the functioning of the Residency Programs is, "Upon entering the residency program at UFRGS, were all the instructions about it given to you in verbal and written form?" For this question, 30.9\% said that they did not receive any type of guidance at the beginning of the program, and $6.2 \%$ did not know how to respond. When asked about knowing the internal regulations of the residency to which they belong, 38.3\% said that they did not know how to respond or ignored it (Table 2).

Table 2. Knowledge of the Internal Regulations of the UFRGS Residency. Participants=81

\begin{tabular}{cccccc}
\hline & & $\mathrm{n}$ & $\%$ & Valid percentage & Accumulated percentage \\
\hline \multirow{4}{*}{ Valid } & No & 21 & 25.9 & 25.9 & 25.9 \\
& Don't know & 10 & 12.3 & 12.3 & 38.3 \\
& Yes & 50 & 61.7 & 61.7 & 100.0 \\
\hline
\end{tabular}

Some issues regarding the functioning of the residency programs and their approaches emerged. It is worth mentioning that, when asked whether their activities are divided into practical, theoretical-practical and theoretical, 27 said "No", five "Don't know" and 49 said "Yes", they are divided in this way (Table 2). Regarding questions about multi-professional classes, that is, with other resident colleagues, thus enabling the sharing of knowledge, a significant number said that they have no multi-professional classes $(32.1 \%)$, adding those who do not know how to respond, this number rises to nearly $40 \%$ (Table 3 ). 
Table 3. Theoretical/Theoretical-practical/Practical activities according to Residency Program. Participants $=81$

\begin{tabular}{cccccc}
\hline & & \multicolumn{2}{c}{ Theoretical / Theoretical-practical / Practical } & \multirow{2}{*}{ Total } \\
\cline { 3 - 5 } & & No & Don't know & Yes & \\
\hline \multirow{3}{*}{ Program } & Animal and Public Health & 16 & 2 & 7 & 25 \\
& Oral Health & 3 & 1 & 20 & 24 \\
& Mental Health & 6 & 0 & 12 & 18 \\
& Public Health & 2 & 2 & 10 & 14 \\
& Participants & 27 & 5 & 49 & 100 \\
& \% & 33.3 & 6.2 & 60.5 & 81 \\
\hline
\end{tabular}

\section{Qualitative Results}

Three conceptual themes result from the analysis of the qualitative information. The first theme was named "Actual vs. Ideal", divided into four categories: "Life experience", "Frustrated expectation", "To have a voice" and "The residents themselves". The second theme includes questions about administration, named "Management of the residency", divided into the following categories: "Organization", "Tutoring time", "Workload" and "Integration among residencies". The third and final theme deals with apprenticeship learning in the residencies, and is named "Learning experiences". The following categories are included: "Guidance", "Theoretical classes", "Making sense" and "Relationship with a mentor".

Based on the observed results, it is possible to find relationships between the statements from the focus groups and the quantitative results. This makes it possible to approach the quantitative and qualitative results in an integrated way. Thus, the results will be discussed together.

\section{DISCUSSION}

\section{Management of the Residency}

\section{Organization}

The study showed that $30.9 \%$ of the residents said that they did not receive any type of verbal or written guidance upon entering the program. Relating to the qualitative analysis, we have the statements of two residents in the theme "Management of the residency", in the category "Organization":

I didn't have any space and I was not met by the personnel... I was not met for anything like that, and I am just going with the flow (GF2_RJ).

[...] they left us hanging... and so there are moments that are good but there are moments that you would need a teacher's opinion (GF1_R1).

These two statements express how the resident felt, in a search for a welcome and making sense, in relation to the lack of organization and of clarifications. They also show that disorganization reflects in the lack of perspective and predictability throughout the program, giving rise to insecurity: 
And like that, they could do it when you enter the residency, "oh, you'll have so many subjects, these subjects" I don't know what will happen next (GF2 _R6).

Nevertheless, when questioned about having knowledge of the internal regulations of the Residency Program, 38.3\% of the respondents answered that they either did not have any knowledge of it or did not know if they knew about it. This is noticeable in the following statements:

[...] but this is one thing that I complain about since I entered the residency, it is not organized and things are organized in a way that is not logical, there is no logical sequence of events... (GF2_R4).

Or there should be a more home-like organization, to make the most of every field in which we are working... (GF1_R2).

\section{Interaction Among Residencies}

The residents were also asked about the presence of multi-professional classes and activities. Most responded to the questionnaire that yes, there was integration with other residencies. This perception was also observed in the focus groups.

In the first place that I worked, there were interns, nursing interns, and for me it was a very good experience to work together, I liked it a lot, and today there are a lot of residents, you are a medical resident and then we go out to do Home Visits (VD) together, so it is very interesting (GF2_R9).

However, gaps were found when addressing the integration among the different Residency areas. The fact that most participants in the focus groups were from the Oral Health area, which is a uni-professional residency, showed that there are no subjects integrating different areas. There are moments of integration in the practical settings, not necessarily followed by reflection on the inter-professionality.

\section{Tutoring Time}

Regarding the tutoring time and the mentoring they have in the programs, the responses were divergent. In particular, the lack of time for tutoring processes. This may be due to the facts listed in the following statements:

Another challenge was not having tutoring time, and we didn't have this in the residency. We had that in the internship and now because we have already graduated... (GF1_R1).

The dissatisfaction with the issue of tutoring time is evident, and happens in an informal way:

[...] we try to express ourselves and to discuss our problems even to get the support of our colleagues, and this is done in an informal way, and I think the the main thing about the residency is this feedback... (GF1_R3).

\section{Workload}

The participants reported difficulties regarding the workloads to which they are submitted, regarding the excessive activities and functions that are under their responsibility in the Residency: 
It is difficult for us to adapt to the many hours a week that we had to fulfill, classes, activities to carry out in addition to the scheduled hours that we were present in the units or in class... (GF2_ $\mathrm{R} 2)$.

One study on Burnout syndrome in residents says that the professional training process can be very tiring for young people. It suggests that residency programs are exhausting professional experiences, which may be related to the consequences of the program format, such as sleep deprivation, fatigue, excessive assistencial workload and problems related to the quality of instruction and to the educational environment ${ }^{14}$.

\section{Learning Experiences}

\section{Theoretical Classes}

The residents also responded about their daily activities, if they were divided into theoretical, theoretical-practical and practical. Here, we had a contingent of 39\%, therefore a significant part, responding "No". According to Resolution no 5 from CNRMS in $2014^{15}$, in art. $2^{\circ}$ it is stated that Residency Programs in the Health professional area, in both the Uni-professional and Multi-professional modalities, will have a workload of $80 \%$ practical and theoretical-practical activity and $20 \%$ in theoretical educational strategies. There is a point to be observed here, that appears in the statements in the category titled "Theoretical classes".

And also some unnecessary classes, I think that highly theoretical classes..., the residency should be focused much more on practice (GF1_R3).

Oh, I just miss the theoretical class, you know, the theory that I don't have, I don't have a theory about... The theory I have is only what I have here with you... (GF2_R8).

This apparent contradiction is worth noting in that, on the one hand, the residents comment that they have many theoretical classes that often do not converge with their daily practice, and others that expect to have more theoretical classes about their professional core. It is important to note that, since these are focus groups having distinct emphases, the configurations of each program are also distinct.

\section{Making Sense}

When questioned about the link between their workplaces and the SUS, the vast majority responded positively to this question: 69 of the 81 interviewees. This is a requirement of art. 24 o of CNRMS Resolution $n^{-}{ }^{710}$, which states the following:

Art. 24. Supervision will be conducted by CNRMS to ensure compliance of the offer of Residency Programs in the Health professional area with the applicable legislation and with the qualification of the systems, services and policies of the Unified Health System (SUS).

The residents' statements show this positive experience in the SUS, thus providing evidence of them making sense from these experiences:

And I also think that working with different people, in different internship fields, is very enriching, but to know the network and see that there are problems, and that in fact they aren't that large (GF2_R3). 
It is like you graduate, then you specialize, then you finish it and go to work in a Center of Odontological Especialties [CEO], for example, you don't even know how the patient got there, and you are treating his "wisdom tooth", you do not know his life-experience (GF2_R3).

Fernandes et al. ${ }^{16}$ mention that residency represents a milestone in the training of healthcare workers, since it's an innovative proposal that is commited to the principles of SUS, enabling qualified health care at different levels of health care.

\section{Relationship with a Mentor}

During the focus groups, interviewees were asked about the relationship between the resident professionals and the workers:

I think that the problem is [...] residents are seen as labor, a workforce, got it? It's cool to have a resident because the resident sees patients, works alone and I [the mentor] can stay seated, doing nothing while they work... (GF2_R6).

Likewise, speeches similar to that are found in other studies. Residents reported that when they assumed activities as if they were team workers, this made them uncomfortable. Nevertheless, they took on service schedule rotations due to the lack of workers, to meet the demands, and this was seen positively by the team, since what mattered was to be productive with no room for discussion with a teacher or a mentor ${ }^{16}$.

Based on the relationship with the tutor and mentor, some residents related their experiences in the teams and in the work places:

I already felt disrespected within an internship place... other people have also already reported the same [...] they did not even say anything because they think this is it, I am a resident and they are the mentors, they are the employees and I have no right to talk about this... (GF2_R4).

A study by Cheade et al. ${ }^{17}$ reports that one of the difficulties with implementing multiprofessional residencies is that many mentors and tutors did not have their academic training based on multi-professional work or in the search for integrality. This could be a causative factor for discrepancies between what is desired in the training of the residents and what is found in the real life of the practical scenarios.

\section{The Counterpoint between Actual vs. Ideal}

\section{Life Experience}

The residency is an intense period of in-service learning and of life experience regarding the search for the development of a more humane professional, with a distinct oulook, more focused on integrality and equity. This is highlighted in the following statements:

[...] I fell in love, I found myself, I grew up a lot, but what was more important was my change as a human being, it was a change in the way I see the world (GF2_R6).

[...] the whole burden of the work, the responsibility, caring for real patients, resolving cases, having autonomy, I think that makes us grow a lot; in adversity then ... wow ... (GF1_R3). 
According to a study conducted at the School of Public Health of Ceará18, residency seeks to translate a didactic system guided by the development of the knowing (Knowledge), of the doing (Skills) and of the being (Attitudes) (CHA) of resident professionals, as well as the transcribed above in the statements. Therefore, in-service training has the potential to offer real life situations to someone who still lacks experience, in a multi-professional environment, and with a person of reference who is the mentor. This has great potential for the development of attitudes and skills, in the actual experience of work in the SUS.

\section{Frustrated Expectation}

In contrast, the following statements represent the disappointment with the reality of some residents in the course of the residency program:

I entered the residency program one person and I'm leaving another [...] I think it was a negative experience because I saw the wrong things that happen in public service [...] that before the residency I didn't know (GF1_R1).

This statement shows residents' discontent and frustration in relation to their actions in the service places. That is, the resident comes to renew the team and bring new perspectives, and yet, the team can be uncompromising and inflexible with dynamics and work relationships already established. The presence of a resident has the potential to renew the discussions about the work process and health care practices: the aim is that the service is qualified by the presence of the resident.

\section{To Have a Voice}

In contrast to the previous statements in the "frustrated expectation" category, the following statements show an attempt to conquer space within UFRGS, especially in the relationship with teachers and tutors:

I always felt that I had the opportunity to discuss things, both in class and within the practical field (GF2_R5).

The teachers ... this helps you to put things into perspective, I think this is a good and positive point, they are very open, they listen, they consider what you say... (GF2_R10).

These statements show that the Residency Program seeks its legitimacy and significance within the University, giving a voice to its residents - allowing them to be empowered and defending their ideas. Thus, residents' representatives participate in the Núcleo Docente Administrativo Estruturante (NDAE - Structural Administrative Teaching Core), and participate in all the discussions and decisions related to the management of UFRGS' residency programs.

\section{The Residents Themselves}

The residency is a teaching-learning process, which aims to meet the principles and guidelines of the SUS in order to transform the model of training the workers. Residents reported some difficulty on the part of permanent workers in understanding the residents' functions within the services: 
According to Mendes ${ }^{19}$, recognition is a central element in the constitution of the integrality of the worker. That is, when there is no exchange dynamic in the work, based on their actions, the worker suffers. However, there is a certain recognition of the residents' role by those who have already gone through the same teaching-learning process:

But just ask those in the network [...] any service that has a resident thinks it is much better, that it works faster (GF1_R3).

A study that evaluated the perception of the actors involved, about the contribution of having a resident in the health teams, showed that the inclusion of more workers from different professions enables more comprehensive health care for families. It also showed that collective actions for health promotion and prevention were established and recognized as new work tools ${ }^{18}$.

The results of this study showed a process of accommodation of different worldviews for a group of residents of the UFRGS residency programs who participated in this study. There is a profusion of positions, sometimes aligned, sometimes dissonant. However, it is clear that the groups were able to express themselves freely, and the results expressed here have no theoretical or political filter.

\section{CONCLUSION}

This study, using quantitative and qualitative methodologies, is a first experience to evaluate UFRGS Residency Programs, aiming to offer residents the opportunity to build their own assessment. It revealed the successes and mistakes of the programs, offering a value judgment (evaluation) that wants to indicate at all levels of the Residency, teaching, service and management, what needs to be improved and what is working well, ways that can help the Residency in its mission.

This and other universities need to understand that in-service training is the most powerful way to prepare professionals for the SUS. This is the mission of the Residency, and it is the responsibility of universities, especially the public universities, to host Residency programs and provide conditions for their full development.

\section{REFERENCES}

1. Brasil. Ministério da Saúde. A construção do SUS: história da reforma sanitária e o processo participativo. Brasília: Secretaria de Gestão Estratégica e Participativa; 2006.

2. Dallegrave D, Kruse MHL. No olho do furacão, na ilha da fantasia: a invenção da residência multiprofissional em saúde. Interface. 2009;13(28):213-26. http://dx.doi.org/10.1590/S141432832009000100018.

3. Ceccim RB, Feuerwerker LCM. 0 quadrilátero da formação para a área da saúde: ensino, gestão, atenção e controle social. Physis. 2004;14(1):41-65. http://dx.doi.org/10.1590/S010373312004000100004.

4. Brasil. Ministério da Saúde. Residência multiprofissional em saúde: experiências, avanços e desafios. Brasília: Ministério da Saúde; 2006.

5. Brasil. Ministério da Saúde. Ministério da Educação. Relatório de atividades da Comissão Nacional de Residências Multiprofissionais em Saúde. CNRMS: exercício: 2007/ 2009 [Internet]. Brasília; 2009 [cited 2017 Nov 20]. Available from: http://www.sbfa.org.br/portal/pdf/Relatorio\%20Atividades\%20CNRMS\%202007\%202009.pdf 
6. Brasil. Ministério da Saúde. Secretaria de Gestão do Trabalho e da Educação na Saúde. Departamento de Gestão da Educação na Saúde. Residência multiprofissional em Saúde: experiências, avanços e desafios. Brasília: Ministério da Saúde; 2006.

7. Brasil. Ministério da Saúde. Resolução no 287 de 8 de outubro de 1998. Diário Oficial da União. Brasília, 8 out. 1998.

8. Brasil. Ministério da Educação. Lei no 11.129, de 30 e junho de 2005. Institui o Programa Nacional de Inclusão de Jovens - ProJovem; cria o Conselho Nacional da Juventude - CNJ e a Secretaria Nacional de Juventude; altera as Leis no 10.683, de 28 de maio de 2003, e 10.429, de 24 de abril de 2002; e dá outras providências. Diário Oficial da União. Brasília, 1 julho 2005.

9. Silva JC, Contim D, Ohl RIB, Chavaglia SRR, Amaral EMS. Perception of the residentes about their performance in the multidisciplinary residency program. Acta Paul Enferm. 2015 Apr;28(2):132-8. http://dx.doi.org/10.1590/1982-0194201500023.

10. Brasil. Ministério da Educação. Secretaria de Educação Superior. Comissão Nacional de Residência Multiprofissional. Resolução no 7, de 13 de novembro de 2014. Regulamenta os processos de avaliação, supervisão e regulação de programas de Residência em Área Profissional da Saúde. Diário Oficial da União. Brasília, 13 novembro 2014.

11. Strauss A, Corbin J. Pesquisa qualitativa: técnicas e procedimentos para o desenvolvimento de teoria fundamentada. 2a ed. Porto Alegre: Artmed; 2008.

12. Buss TM, López Monesinos MJ, Adrize RP, Coelho AS, Oliveira Arrieira IC, Marzena M. Grupo focal: una técnica de recogida de datos em investigaciones cualitativas. Index Enferm. 2013 Jun;22(1-2):75-8. http://dx.doi.org/10.4321/S1132-12962013000100016.

13. Charmaz KA. Construção da teoria fundamentada: guia prático para análise qualitativa. Porto Alegre: Artmed; 2009.

14. Guido LA, Silva RM, Goulart CT, Bolzan MEO, Lopes LFD. Síndrome de Burnout em residentes multiprofissionais de uma universidade pública. Rev Esc Enferm USP. 2012 Dez;46(6):1477-83. http://dx.doi.org/10.1590/S0080-62342012000600027. PMid:23380794.

15. Brasil. Ministério da Educação. Secretaria de Educação Superior. Comissão Nacional de Residência Multiprofissional. Resolução no 5, de 7 de novembro de 2014. Dispõe sobre a duração e a carga horária dos programas de Residência em Área Profissional da Saúde nas modalidades multiprofissional e uniprofissional e sobre a avaliação e a frequência dos profissionais da saúde residentes. Diário Oficial da União. Brasília, 10 novembro 2014.

16. Fernandes MNS, Beck CLC, Weiller TH, Viero V, Freitas PH, Prestes FC. Sofrimento e prazer no processo de formação de residentes multiprofissionais em saúde. Rev Gaúcha Enferm. 2015 Dez;36(4):90-7. http://dx.doi.org/10.1590/1983-1447.2015.04.50300. PMid:26735764.

17. Cheade MFM, Frota OP, Loureiro MDR, Quintanilha ACF. Residência multiprofissional em saúde: a busca pela integralidade. Cogitare Enferm. 2013;18(3):592-5.

http://dx.doi.org/10.5380/ce.v18i3.46360.

18. Gadelha AKS, Barreto ICHC. Integrated residency in Health: perception of the players with emphasis on Family and Community Health. Interface. 2018;22(Suppl 1):1339-51. http://dx.doi.org/10.1590/1807-57622017.0183.

19. Mendes AM. Psicodinâmica do trabalho: teoria, método e pesquisas. São Paulo: Casa do Psicólogo; 2007.

\section{CONFLICTS OF INTERESTS}

The authors declare no conflicts of interest. 


\section{*CORRESPONDING AUTHOR}

Renato José De Marchi, UFRGS - Universidade Federal do Rio Grande do Sul, Faculdade de Odontologia, Av. Ramiro Barcelos, 2492, Santa Cecília, 90035-003 Porto Alegre - RS, Brasil, email: renatodmarchi@gmail.com

Received: February 14, 2020

Accepted: April 27, 2020 